\title{
The Unintended Consequences of Bilateralism: Treaty Shopping and International Tax Policy
}

Vincent Arel-Bundock, Université de Montréal

February 28, 2017

Abstract: The international tax system is a complex regime composed of thousands of bilateral tax treaties. These agreements coordinate policies between countries to avoid double taxation and encourage international investment. I argue that by solving this coordination problem on a bilateral basis, states have inadvertently created opportunities for treaty shopping by multinationals. These opportunities, in turn, reduce the potency of fiscal policy, put pressure on governments to change their domestic tax laws, and ultimately constrain state autonomy. This constraint is theoretically distinct from the usual race-to-thebottom story and it generates different testable implications. I use a motivating case study to show how multinationals leverage the structure of the treaty network to reduce their tax burden. Then, I develop a new measure of treatyshopping opportunities for firms in 164 countries. Where the proliferation of tax treaties allows multinationals to engage in treaty shopping, states' fiscal autonomy is limited, and governments tend to maintain lower tax rates. 
The global investment regime, the international tax system, and much of world trade are governed by bilateral treaties. Received wisdom holds that the principle of specific reciprocity which underpins those treaties "segments relations into multiples of dyads and compartmentalizes them."[ When capital is mobile, however, the effects of a bilateral agreement may not remain confined to signatory parties, even if all the benefits that it confers are purely reciprocal. I explore some of the unintended consequences and negative externalities that arise when global economic governance is conducted via thick, decentralized networks of bilateral treaties.

I consider these problems in the context of the international tax system, a complex regime ${ }^{2}$ composed of thousands of Bilateral Tax Treaties (BTTs). The main purpose of these agreements is to solve a thorny coordination problem: double taxation. While most states want to tax multinational corporations (MNCs), they also have incentives to coordinate policies to encourage international investment and ensure that profits are not taxed in multiple jurisdictions at once.

Double taxation is a fundamentally political problem because any solution involves splitting the tax base between countries. Historically, the distributional concerns associated with this process have made it very difficult for national governments to reach multilateral agreement on tax base allocation. In the absence of broad-based cooperation, bilateral treaties have emerged as a second-best solution.

Over the past half century, BT Ts have been largely successful in eliminating double taxation. Bilateralism, however, has also had unintended consequences. In particular, the decentralized structure of the governance regime now allows MNCs to dodge taxes by engaging in treaty shopping.

Multinationals often deploy sophisticated corporate structures that span many countries to optimize their taxes. One common strategy is for firms to channel international transactions through subsidiaries in countries with well-developed portfolios of BTTs. By making transactions indirectly through strategically located conduits, firms can string together the benefits of several treaties and circumvent the taxes that would otherwise be withheld from international payments. MNCs' ability to send funds along such cheap indirect pathways endows them with a powerful exit threat: if governments maintain heavy taxes on cross-border payments, firms can use treaty shopping to escape those taxes.

The extent to which treaty shopping constrains governments' ability to tax depends on the structure of the treaty network. When two countries sign a BTT, they clear a new path through which firms can channel funds. As I will explain, this cre-

\footnotetext{
${ }^{0}$ I thank Timm Betz, André Blais, Cristina Bodea, Bill Clark, François Claveau, Peter Dietsch, Clément Fontan, Rob Franzese, Andrew Kerner, Walter Kowalski, Sébastien Mainville, Mark Manger, Theo McLauchlin, Frédéric Mérand, Jean-Frédéric Morin, Krzysztof Pelc, Amy Pond, Phil Potter, Thomas Rixen, Kevin Young, the $I O$ editors and anonymous reviewers.

${ }^{1}$ Ruggie 1992, 571

2 Raustiala and Victor 2004
} 
ates avoidance opportunities for firms both inside and outside the formal geographic scope of the agreement. A BTT can thus reduce the effectiveness of taxes imposed by third-party governments, even if those governments did not agree to be bound. In other words, bilateral treaties can impose negative externalities that states ignore at their own peril.

In sum, by using bilateralism to solve a coordination problem, states have inadvertently created opportunities for treaty shopping by multinationals. These opportunities, in turn, reduce the potency of fiscal policy, put pressure on governments to change their domestic tax laws, and ultimately limit state autonomy.

This argument speaks to key debates in International Relations on what Susan Strange calls The Retreat of the State. On one side, authors like Strange and Dani Rodrik have argued that "the impersonal forces of world markets [are] now more powerful than the states" 3 and that they pose a threat to the bargain of embedded liberalism. ${ }^{-1}$ On the other, several researchers have pushed back against what they perceive as The Myth of the Powerless State. ${ }^{5}$ I stake a middle ground between these two positions: while states appear to retain a fair amount of agency in the design of global governance regimes, the choices they make can come back to bite them. In solving coordination problems through bilateralism, national governments have created a decentralized tax system that now constrains their fiscal autonomy and empowers multinationals.

This conclusion is consonant with the voluminous literature on "international regime complexity," a concept understood as "the presence of nested, partially overlapping, and parallel international regimes." ${ }^{\prime 6}$ But while most prior works in that tradition focus on how governments manipulate (or create) regimes, 7 I remind readers that private actors can also exploit complexity. When capital is mobile and firms engage in treaty shopping, bilateral agreements produce spillovers and have unintended consequences. As Robert Jervis put it, in complex systems, "we can never do merely one thing." 8

These lessons have broad applicability because the specific strategies that firms deploy in the tax field find close analogues in other areas of international political economy. While Google makes indirect payments to circumvent withholding taxes, Indian traders ship goods to Pakistan indirectly, from Mumbai to Karachi via Dubai, to avoid onerous border controls and trade restrictions.10 The problems posed by indirect trade routes are so pervasive that virtually all preferential trade agreements

\footnotetext{
${ }^{3}$ Strange 1996, 4

Rodrik 1997, 66

${ }^{5}$ Weiss 1998

${ }^{6}$ Alter and Meunier 2009, 13

${ }^{7}$ See Pekkanen, Solís, and Katada 2007; Busch 2007; Kelley 2009.

${ }^{8}$ Jervis 1998, 10

${ }^{9}$ Kleinbard 2011

${ }^{10}$ De, Raihan, and Ghani 2013
} 
now include rules of origin to prevent trade deflection and tariff jumping. Similar issues also arise with foreign direct investment. For instance, we know that some firms establish subsidiaries outside their home or host countries to launch investorstate dispute-settlement proceedings. By bringing suit indirectly, from a well-chosen third-party country, these firms can often benefit from the protection of stronger bilateral investment treaties.11 In short, the problem structure that I examine here is not sui generis. Paying close attention to how multinationals use global value chains to circumvent regulation and claim protection under international agreements can illuminate several different problems in IR, and inform the design of solutions to those problems.

Three types of empirical evidence support my arguments. First, a motivating case shows that MNCs use chains of ownership to exploit the network structure of the international tax regime. By sending funds indirectly through a Dutch conduit, Google avoided paying a hefty withholding tax to the Irish government.

Second, primary source material and econometric evidence suggest that the Google anecdote is part of a broader pattern. Many multinationals seem to use the treaty-shopping opportunities afforded to them by the proliferation of BTTs.

Finally, to systematically assess the effect of bilateralism on states' fiscal autonomy, I develop a new measure of treaty-shopping opportunities for firms in 164 countries. Formally, this variable measures the shortest weighted path between every pair of countries in the sample. More intuitively, my new measure records the minimum tax rate that an $\mathrm{MNC}$ can expect to pay when it engages in treaty shopping and makes cross-border payments indirectly through conduits.

This variable is useful as a descriptive tool: it shows that governments' decision to coordinate policies on a bilateral basis makes it easy for multinationals to circumvent withholding taxes. It also shows that treaty shopping can drastically reduce a firm's tax liabilities.

More to the point, the measure allows us to assess the consequences of bilateralism for policy-making. Where the BTT network endows firms with credible exit threats, I expect governments to respond by lowering their taxes. Empirically, this implies that the presence of cheap indirect pathways should be correlated with (direct) withholding tax rates. And this is indeed the case: governments appear to adjust policy in response to the structural constraints imposed by the tax treaty network.

The relationship between direct and indirect tax rates subsists, even after we control for more traditional patterns of spatial dependence between jurisdictions. This implies that fiscal interdependence cannot simply be understood as a race-tothe-bottom. States do not just compete against one another, but also against the low effective tax rates that apply when firms exploit the network structure of the interna-

\footnotetext{
${ }^{11}$ Harten and Loughlin 2006; Gray 2016
} 
tional tax system. The constraints that tax competition and treaty shopping impose on policymakers are both theoretically and empirically distinct.

Unlike preferential trade or investment agreements, BTTs remain woefully understudied in political science.12 This oversight is consequential, because tax treaties are the linchpin of an institutional framework that has come to limit states' capacity to finance public goods. Clausing estimates that American multinationals sent over $\$ 180$ billion abroad to reduce their tax bill in 2004. 13 If accurate, this estimate would entail a $\$ 60$ billion shortfall in revenue for the US government, the equivalent of a 35 percent reduction in corporate income tax.14 These figures, and recent investigations into the tax deals of companies like Fiat and Starbucks ${ }^{15}$, make plain that tax avoidance can have severe consequences for public finance and for the distribution of tax burden across society. Understanding the policies that allow firms to dodge taxes thus imposes itself as an imperative for social scientists.

\section{BILATERAL POLICY COORDINATION AND THE TAX TREATY NETWORK}

The principles that underpin the modern international tax system were laid down in the inter-war years, when states faced great pressure to service war debts and pay for reconstruction. Recognizing that the poor state of public finance could lead governments to take actions that would be inimical to economic recovery, the League of $\mathrm{Na}$ tions convened several rounds of consultation between representatives of national tax authorities. The chairman of these proceedings, the American lawyer Mitchell B. Carroll, framed the problem like this:

While many countries were in desperate need of capital, whether in the form of loans to the Government or investment in local enterprises, their Governments often sought to impose such high taxes on interest or dividends as to constitute a serious barrier to the influx of wanted funds. In short, the grasping for revenues was tending seriously to obstruct efforts to restore trade, and business enterprises were so restricted by the network of tax liabilities that they hesitated to assume the risks of foreign commerce, which were serious enough apart from any question of tax liability. ${ }^{16}$

\footnotetext{
${ }^{12}$ On the effect of BTTs on FDI, see Blonigen and Davies 2004; Barthel, Busse, and Neumayer 2009; on the development of the treaty network, see Rixen 2008; Rixen and Schwarz 2009; Rixen 2010 Barthel and Neumayer 2012.

${ }^{13}$ Clausing 2009

${ }^{14}$ For more conservative assessments, see Dharmapala 2014; Hines 2014.

${ }^{15}$ European Commission 2015

${ }^{16}$ Carroll 1939, 7-8
} 


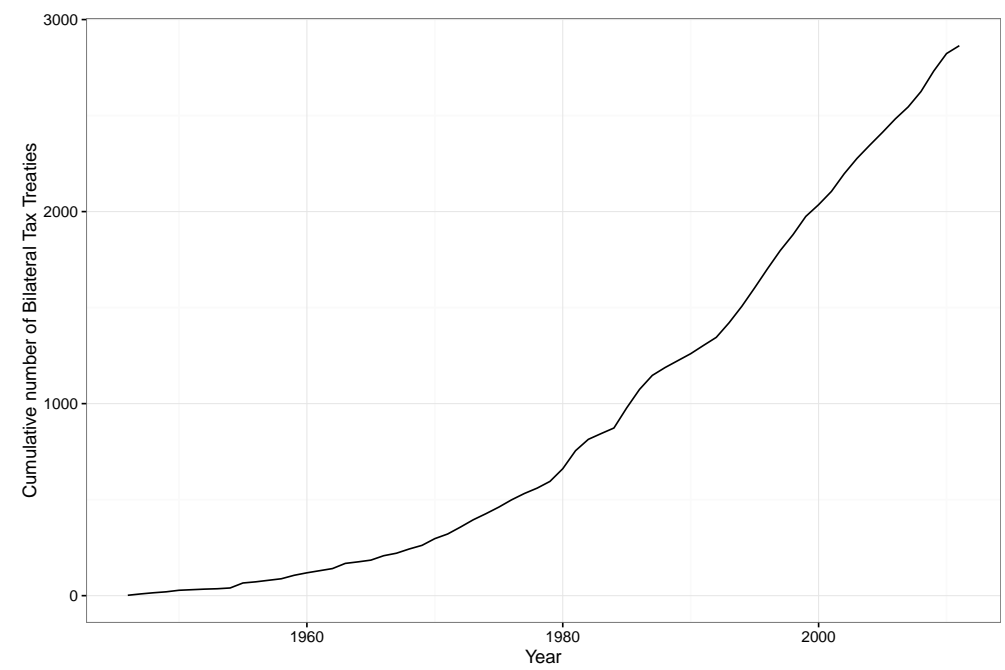

Figure 1: Cumulative number of Bilateral Tax Treaties signed worldwide.

He highlights the two main issues that arise when multiple jurisdictions claim the right to tax the same income. First, when a multinational's profits are taxed by both its home and its host, the effective tax rate may become much higher than if that firm's activities were purely domestic. Obviously, this situation is undesirable, because it deters international investment.

Second, any solution to this double taxation problem entails deep distributional consequences, because it involves splitting the tax base between countries. As Rixen aptly put it, tax base apportionment can be understood as a coordination game with distributional consequences, akin to the so-called battle of the sexes: both parties wish to find an agreement that limits double taxation, but the terms of that agreement can yield asymmetric benefits.17

Members of the Carroll working group quickly realized that, in this strategic context, reaching agreement on a multilateral compact between capital-exporting and capital-importing countries would be politically infeasible. The focus of negotiations thus shifted to the design of a shared treaty model that could be customized in bilateral talks. After World War II, this work was carried forward by the OECD Committee on Fiscal Affairs, which published a series of highly influential Model Tax Conventions. Since then, thousands of bilateral tax treaties have been ratified, most of them based on the OECD model (Figure ).

BTTs are the cornerstone of the international tax system; they coordinate states' policies across a range of complex issues. For the purpose of this study, it suffices to highlight three.

\footnotetext{
${ }^{17}$ Rixen 2011
} 
Source-based taxation. First, states must decide how to tax the income that is generated within their borders by foreign-based MNCs. Today, host countries generally hold primary jurisdiction to tax the active income 8 that is earned in their territories by foreign or domestic firms with permanent establishments. .19

Residence-based taxation. Second, the state where a multinational resides has to choose whether it will impose a corporate income tax on the profits that the company earns abroad. Most developed economies have adopted "territorial" tax systems, which means that they ignore the foreign-earned active income of their own MNCs. A small number of countries, including the United States, impose a "worldwide" tax on their multinationals, but grant credits for taxes paid to foreign governments. 20

Withholding taxes. Third, a government must fix the withholding tax rates that apply to payments made from inside its territory to parties abroad. The distinctive feature of withholdings is that, unlike sales taxes for example, they are remitted to the tax authority by the (domestic) payer rather than the (foreign) recipient. This is useful in the international context, because it obviates the need for government to interact with foreign entities. Withholding taxes are typically applied to three categories of cross-border flows: interest, dividends, and royalties. States publish statutory rates for each category, and preferential treatment is often given to BTT partners.

The American government withheld $\$ 10.1$ billion on payments to foreigners in 2010,21 but this amount understates the revenue potential. As Figure 2 shows, real growth in US-source income to foreigners far outpaced the increase in taxes collected (545 percent and 118 percent respectively over the 1989-2011 period). And although the paucity of data makes it difficult to ascertain, it has long been recognized that withholding taxes could matter more in developing economies, where they sometimes act as a complement to lower effective tax rates.22

Withholding taxes also play an important role in intergovernmental relations, where they act as a bargaining chip for bilateral negotiation. In his memoirs, Mitchell B. Carroll recounts that when the French government dithered before ratifying the

\footnotetext{
18 "Active income" is distinguished from "passive income", which is either produced by a rental activity or through a "business in which the taxpayer does not materially participate (Internal Revenue Service, 2004)."

${ }^{19} \mathrm{~A}$ permanent establishment is a fixed place of business such as an office, branch, factory, or place of extraction of natural resources that lasts for more than a set period of time (e.g., twelve months) (Avi-Yonah, 2007, 82).

${ }^{20}$ This credit is analogous to the foreign income tax credit that is granted to US citizens who work abroad and pay taxes to a foreign government. Note that the foreign-earned income of American corporations is typically taxed by the IRS only once it is repatriated.

${ }^{21}$ Internal Revenue Service 2010

${ }^{22}$ OECD 1964
} 


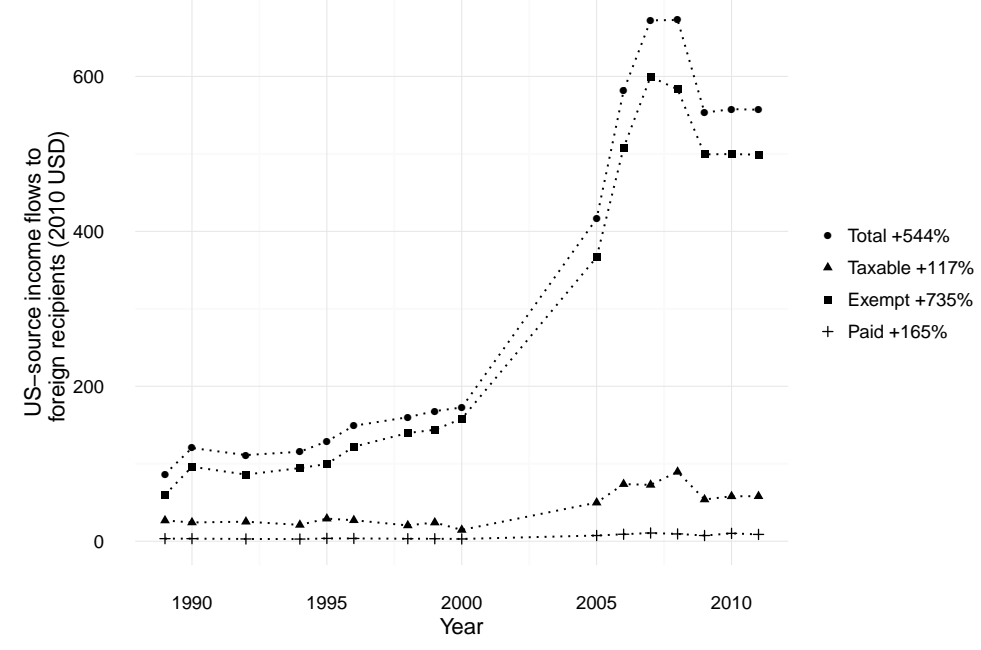

Figure 2: Taxes withheld on US-source income to foreign recipients. Source: IRS, Statistics of Income Division.

1936 US-France tax treaty, the French Ministry of Foreign Affairs was notified that Congress had authorized an 80 percent tax "on residents of a country that imposed on US taxpayers discriminatory or extraterritorial taxes[.] The recipient official was said to have a goodly portfolio of American securities and saw himself bearing a rate of 80 percent deducted from dividends at source." 23 The treaty was ratified shortly thereafter. ${ }^{24}$

Beyond revenue generation and intergovernmental bargaining, the aspect of withholding taxes that bears most directly on my argument relates to the tax optimization strategies of multinationals. It is well known that several MNCs shift profits from high-tax to low-tax jurisdictions using a set of techniques known as "earnings stripping." 25 Consider the hypothetical case of a Bermudan company that finances the operations of a related party in the United States through large loans. Depending on the terms of the intra-firm agreement, the American firm could have to send back much of its profits to Bermuda in the form of interest and capital repayment. This would reduce the MNC's reported earnings in the high tax jurisdiction and increase them in the low tax jurisdiction. Analogous stripping techniques could work through equity investment or intellectual property rights, in which case flows from the US to Bermuda would take the form of dividends or royalties. Obviously,

\footnotetext{
${ }^{23}$ Carroll 1978, 41-42

${ }^{24}$ For a recent example, see Christians and Cockfield 2014 on the Foreign Account Tax Compliance Act of 2010.

${ }^{25}$ Another well-known approach to tax avoidance is transfer pricing.
} 
imposing a large withholding tax on cross-border flows of interest, dividends, or royalty payments would hinder this type of tax optimization strategy.

\section{THE UNINTENDED CONSEQUENCES OF BILATERALISM: A CASE STUDY}

BTTs can be touted as successful instances of international cooperation. By coordinating source, residence, and withholding taxes, these agreements have largely resolved the problem of double taxation. However, a system of global economic governance that rests on bilateralism can also produce second-order cooperation problems. ${ }^{26}$ By using BTTs to coordinate their policies, states have allowed firms to exploit the governance regime in ways that limit the efficacy of fiscal instruments and undermine public policy goals.

I use a motivating case study to illustrate how multinationals use treaty shopping to minimize their tax liabilities. Put simply, when direct payments between two countries trigger costly withholding taxes, MNCs can shop for favorable treaty terms and establish conduits in third-party states to make cheap indirect payments.

\section{The Double Irish Dutch Sandwich}

The "Double Irish Dutch Sandwich" is a corporate structure used by Google in the late-2000s. Drucker reports that, using this strategy, the company was able to reduce its effective tax rate on non-U.S. income to 2.4 percent in 2010.27

Figure shows a simplified sketch of the structure in question. ${ }^{28}$ It rests on four main components. The parent company Google Inc. is based in California, where it develops most of its search and advertising technology. This entity sells ads and other products to American customers but makes few direct sales outside the United States. Google Inc. enters into a cost-sharing agreement with Google Ireland Holdings, a fully owned subsidiary which, despite its name, 29 has its mind and management in the tax haven of Bermuda. In exchange for financial contributions to R\&D activities, this tax-exempt subsidiary obtains the right to license and exploit Google's intellectual property worldwide.

\footnotetext{
${ }^{26}$ Hale, Held, and Young 2013

${ }^{27}$ Drucker|2010

${ }^{28}$ For a more detailed account, see Kleinbard 2011. As the author writes (note 11), Google's tax planning is not transparent to outsiders, so any inference drawn from publicly available information may mischaracterize the actual corporate structure that the company used.

${ }^{29}$ The "Double Irish Dutch Sandwich" leverages two complementary strategies. It suffices to consider the "Dutch Sandwich" here. The "Double Irish" exploits differences in the residence criteria applied by the United States (location of incorporation) and Ireland (location of management and control). From the perspective of the IRS, Google Ireland Holdings is considered an Irish resident, but for Irish tax purposes, it resides in Bermuda. See Darby and Lemaster 2007.
} 


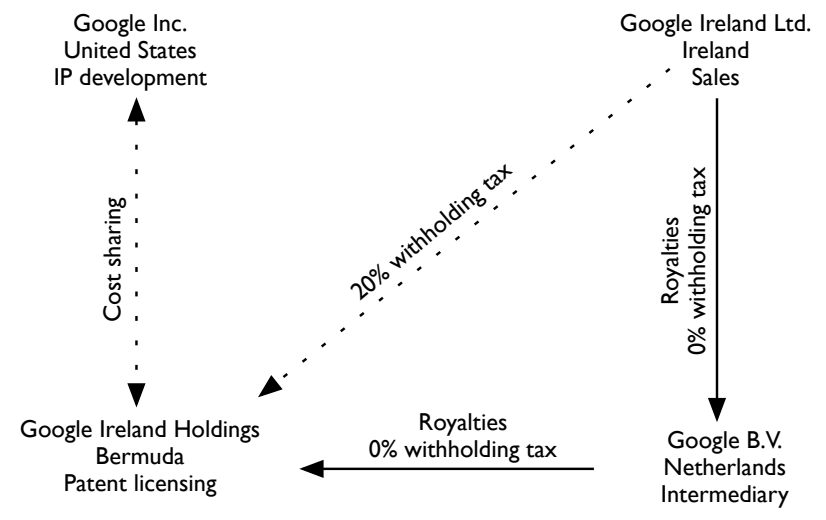

Figure 3: Simplified sketch of Google’s corporate structure in 2009.

From Bermuda, the technology rights are sublicensed to a third entity in the Netherlands (Google B.V.), which has very few employees and does not appear to contribute meaningfully to the development or use of Google's technology. As a Dutch company, Google B.V. benefits from advantageous rates on cross-border payments, thanks to the Netherlands's low tax policy and extensive network of BTTs.

The fourth component of the Dutch Sandwich is Google Ireland Ltd., another subsidiary with a workforce of a few thousands in Ireland. The Dutch Google B.V. sub-sublicenses the technology rights to Google Ireland Ltd., which in turn sells advertising and other products directly to customers in Europe, the Middle East, and Africa.

Now consider the tax implications. Google Ireland Ltd. generates billions of dollars in revenue every year, and its profits are subject to the (comparatively low) Irish corporate tax rate of 12.5 percent. However, since most of the economic value that Google produces can be traced back to intellectual property rather than to the act of sale, the Irish subsidiary must make large royalty payments to the Dutch Google $B$.V. to pay for its licenses. These royalty payments are tax-deductible costs, so little corporate income tax is collected by the Irish government. The royalty payments themselves are not subject to a withholding tax when they leave Ireland because they are sent to the Netherlands, a member of the European Union. Likewise, not much economic value is produced in the Netherlands, and the Dutch government does not impose a tax on outbound payments, so royalties are rerouted almost in whole toward Bermuda. Crucially, royalty payments would have been subject to a 20 percent tax had they been paid directly to Bermuda from Ireland.

In sum, treaty shopping allows Google to exploit the network of bilateral relations between states: making royalty payments indirectly allows the company to 
(legally) circumvent a heavy tax. .30 While purely domestic considerations such as corporate tax rates and incorporation rules continue to guide corporate restructuring decisions, the Dutch Sandwich example suggests that treaty shopping could be an important system-level determinant of firm behavior and fiscal outcomes.

\section{More Than an Anecdote}

There is substantial evidence that the Dutch Sandwich anecdote is part of a broader pattern. In 2014, a former PricewaterhouseCoopers (PwC) employee leaked documents on private tax deals between 340 MNCs and the tax haven of Luxembourg. 31. About two thirds of the documents released explicitly address how the Luxembourg deals would affect the firms' withholding tax bills. Of course, those documents do not reveal the motives behind corporate restructuring decisions, but they do make clear that the incidence of investment decisions on withholding taxes is an important consideration in tax planning. 32

Several economists have examined the relationship between withholding taxes and firm behavior at a more macro level. For example, Weichenrieder and Mintz show that withholding taxes have a significant effect on the establishment of taxpreferred conduits, and Weyzig estimates that "the existence of a Dutch treaty route is associated with approximately six percentage points more bilateral FDI being held via the Netherlands, whereas a direct bilateral tax treaty is associated with three percentage points less." 33

Governments are keenly aware of the phenomenon. Fifty years ago, American and Danish representatives were already expressing concerns over this specific issue to the OECD's Fiscal Committee. ${ }^{34}$ Since then, states have made several (mostly unsuccessful) attempts to curb the practice of tax treaty shopping. .35

These attempts are a natural response to a problem that states have themselves created. By designing an international regime anchored in bilateralism, govern-

\footnotetext{
${ }^{30}$ Kleinbard asserts that most of these royalties will never be subject to US taxation and that the "end result is a near-zero rate of tax" $(2011,713)$. However, the precise value of these tax benefits is difficult to corroborate because it depends on (a) the confidential and IRS-approved terms of the cost-sharing agreement between Google Inc. and its Bermudan subsidiary, and (b) the company's ability to reinvest profits abroad in perpetuity to benefit from American rules on tax deferral.

${ }^{31}$ International Consortium of Investigative Journalists 2014

${ }^{32}$ Another interesting lesson we can draw from the Luxleaks documents is that individual business managers do not need to be personally familiar with the intricacies of the BTT network to engage in treaty shopping. Withholding tax optimization is conducted as a routine step when MNCs hire one of the Big Four accounting firms.

${ }^{33}$ Weichenrieder and Mintz 2008, Weyzig 2013, 926

${ }^{34}$ OECD 1967

${ }^{35}$ On the difficulty of implementing legal countermeasures to treaty shopping, see Haug 1996; on American efforts to curb treaty shopping by terminating BTTs, see Crandall 1988; for examples of court cases in which governments challenged the treaty-shopping practices of MNCs, see Kandev 2009.
} 
ments have allowed firms to engage in practices that now constrain public policies.

\section{TREATY SHOPPING AS POLICY CONSTRAINT}

When two governments sign a bilateral agreement to reduce withholding taxes, they clear a path through which firms can channel funds. By establishing conduits in strategic locations, MNCs can combine several such paths to form a cheap indirect route. This endows multinationals with a powerful exit threat: if governments maintain heavy taxes on direct payments, firms may dodge those taxes by making transactions indirectly.

When a government lowers its withholding taxes, it opens treaty-shopping opportunities for companies in other countries as well. For example, when the Dutch decided not to tax outbound royalty payments to Bermuda, they allowed firms in Ireland to deploy strategies like the Dutch Sandwich. Thus, even if the benefits granted by a BTT are purely reciprocal, its effects may not remain confined to signatory parties. States' decisions with respect to international taxation produce externalities.

Where treaty-shopping opportunities abound, governments' revenue-generation capacity is constrained, and withholding taxes lose much of their usefulness as a tool of economic foreign policy. In that context, governments should adjust policy accordingly: if cheap indirect routes allow multinationals to circumvent heavy taxes, I expect governments to lower their (direct) rates.

This form of policy interdependence is very different from the familiar raceto-the-bottom story. In standard theoretical treatments of tax competition, firms compare the fiscal environment in different jurisdictions and choose where to invest by optimizing over that information. Because companies can pick between more or less substitutable investment sites, host governments undercut each other's tax rates and engage in a race-to-the-bottom. A state's tax policy should thus be a function of its competitors' policies.

Figure illustrates how this differs from the treaty-shopping dynamic that I exposed earlier. In the better-known case of panel (a), country $D$ 's policy toward $A$ depends on $D$ 's competitors' stance vis-à-vis $A$. The directed edge $D A$ is a function of a weighted average of $B A$ and $C A$, with weights typically defined by some measure of proximity between $D$ and its competitors. In contrast, panel (b) shows that, in the treaty-shopping story, $D A$ depends on the cost of the cheapest indirect route between $D$ and $A, \min (D B A, D C A)$.

The two arguments represented in Figure are theoretically distinct, and they have different observable implications. Standard tax competition should lead countries to adopt policies that are similar to their competitors'. In contrast, if treaty shopping acts as a constraint, governments' policies should be a function of the rate that MNCs would pay by sending funds indirectly. To be clear, the two arguments are 


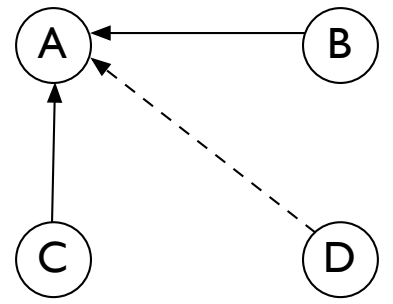

(a) Competition

Weighted average of CA \& BA

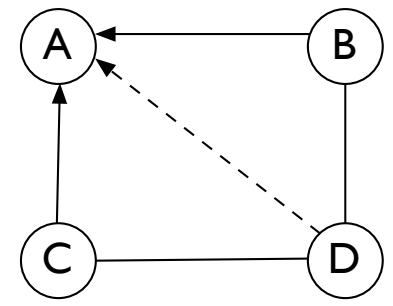

(b) Treaty shopping Minimum of DBA \& DCA

Figure 4: Tax competition vs. treaty-shopping

not mutually exclusive; both constraints could bind simultaneously, but they remain theoretically distinct phenomena, and they should be empirically distinguishable.

\section{DO TREATY-SHOPPING OPPORTUNITIES SHAPE TAX POLICY?}

To assess whether firms' ability to engage in treaty shopping affects states' fiscal autonomy. I create a new measure of "indirect withholding tax" that records the minimum rate that an $\mathrm{MNC}$ can expect to pay when it makes cross-border payments indirectly through conduits. I begin the analysis by presenting simple univariate statistics. This exercise shows that BTTs facilitate tax avoidance through treaty shopping, and that this practice can drastically reduce the withholding tax bills of multinationals. Then, I test my central claim by examining the relationship between direct and indirect withholding tax rates. I find that where MNCs can shop for favorable treaty terms, governments tend to tax multinationals at lower rates. In other words, cheap indirect pathways like the Dutch Sandwich appear to constrain states and drive down direct taxes.

\section{A Measure of Treaty-Shopping Opportunities: Cheapest Indirect Rate}

I assembled a dataset of withholding tax rates for every directed dyad in a sample of 164 countries $\sqrt{36}$ I record the rate that host countries would apply in the absence of a BTT ("base rates") for three categories of flows (royalties, dividends, interest). If a treaty is in place, I also record the rates it specifies ("treaty rates"). The lowest value between base and treaty is the "effective rate".

\footnotetext{
${ }^{36}$ Data on withholding tax rates are from country profiles published by the International Bureau of Fiscal Documentation. At the time of collection these data were only available for a cross-section (2012).
} 
To measure treaty-shopping opportunities, I create an original measure of "cheapest indirect rates". I define this variable as the lowest rate that can apply to payments between a pair of states when transactions are made indirectly, through a third country. In terms of network analysis, this is equivalent to finding the shortest weighted path between nodes in a network where nodes are countries, weights are tax rates, and direct routes are excluded. Formally,

$$
\tau_{i j}^{\prime}=\min _{\forall k \notin\{i, j\}}\left\{1-\left(1-\tau_{i k}\right)\left(1-\tau_{k j}\right)\right\}
$$

where $\tau_{i j}$ is the withholding tax on flows from country $i$ to country $j$, and we iterate over every third-party country $k$ to find the minimum indirect rate $\tau_{i j}^{\prime}$. A low value of $\tau_{i j}^{\prime}$ indicates that treaty shopping allows MNCs to make indirect crossborder payments cheaply.

\section{Exploratory Data Analysis}

A look at descriptive statistics for these measures yields four main insights. First, withholding tax rates would be considerably higher in the absence of tax treaties. Figure shows that the "effective" cumulative distribution function is located to the left of the "base" curve.

Second, the magnitude of this tax cut appears even greater when we allow for arrangements like the Dutch Sandwich: the "indirect" cumulative distribution lies at the top of the graph, and the densities for all three flow categories have modes of 0 percent. Moreover, MNCs who shop for favorable treaty terms can route funds between most pairs of countries without paying any withholding tax at all.

Third, treaty shopping drastically reduces the within-host-country variance in withholding tax rates. For instance, the average variance in bilateral rates on interest across host countries dips from about five to one when we introduce the possibility of indirect payments. In each of the flow categories, over 60 percent of host countries only show one or two distinct values on my indirect tax rates variables. Often, indirect payments drive down withholding tax liabilities to zero. But even where this is not the case, firms can typically be assured that they will pay similar rates when they make indirect payments from host country $i$, regardless of the recipient's location.

\footnotetext{
${ }^{37}$ To be sure, this measure of indirect tax rates is a rough proxy, since it does not account for factors like foreign tax credits or transaction costs. In practice, transaction costs tend to be fixed rather than variable, and also quite low. Findley, Nielson, Sharman et al. 2014, 31 find that shell companies can be formed in minutes for as little as a few hundred dollars. The fact that BTTs tend to follow the OECD model very closely reduces uncertainty and transaction costs, making it easier for firms to shop for favorable terms on the few dimensions along which treaty texts do vary.
} 


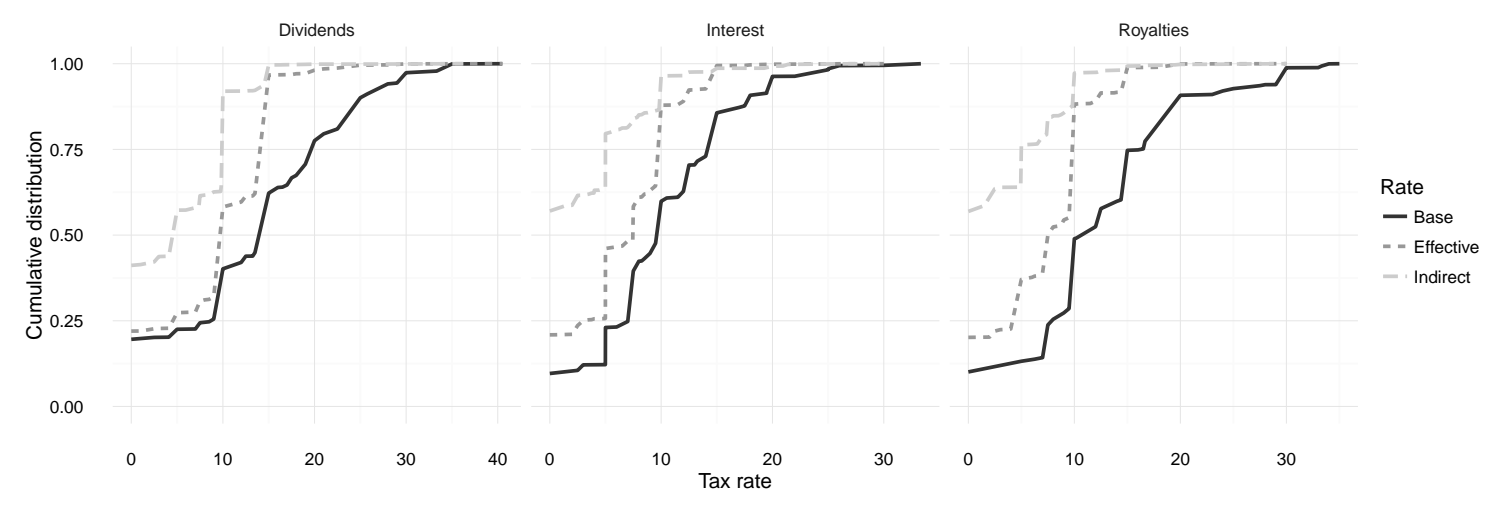

Figure 5: Distributions of base, effective, and indirect withholding tax rates.

Finally, Figure reports the results of a simple counter-factual simulation, which shows that BTTs have a strong effect on treaty-shopping opportunities. Each line represents the distribution of indirect tax rates that would apply if only a (randomly selected) subset of current BTTs were in force $\sqrt{88}$ As the treaty network becomes thicker (darker lines), indirect withholding tax rates are driven down. That is, it becomes cheaper for firms to make indirect payments. 39

\section{Regression Analysis}

Where the indirect tax rate is low, MNCs wield a powerful exit threat, because they can engage in treaty shopping to circumvent direct taxes on international payments. In that context, I expect governments to respond by lowering their own withholding taxes. Empirically, this implies that direct and indirect rates should be positively related.

Figure shows that this is indeed the case. For all three flow types, the LOESS curve slopes upward, which means that indirect rates are positively associated with bilateral rates. Conversely, cheap indirect paths are associated with reduced bilateral rates.

\footnotetext{
${ }^{38}$ The simulation exercise in Figure highlights an important but subtle point: indirect tax rates are not a function of the raw number of BTTs that a particular government signs. Instead, they should be thought of as a combination of treaty depth and partner countries' policies (Figure ). Signing a single "deep" treaty with a hub like the Netherlands can be far more consequential than signing many "shallow" BTTs with high-tax countries. Thus, at the state level, there need be no relationship between the number of BTTs that a specific country signs and the indirect tax rates that firms in that country will pay. The influence of BTT ratification on indirect tax rates operates at the system-level, through network effects. We must not impute a property of the whole to its parts.

${ }^{39}$ Figure also suggests that, from the perspective of firms, there are diminishing marginal returns to new BTTs.
} 


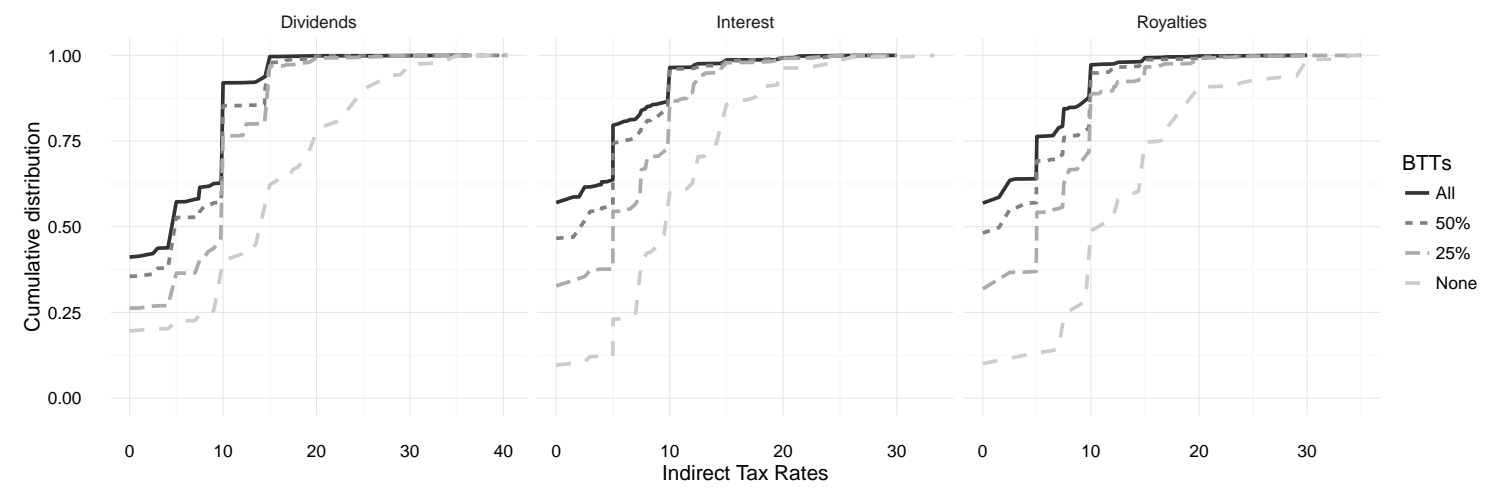

Figure 6: The effect of bilateral tax treaties on indirect withholding tax rates.

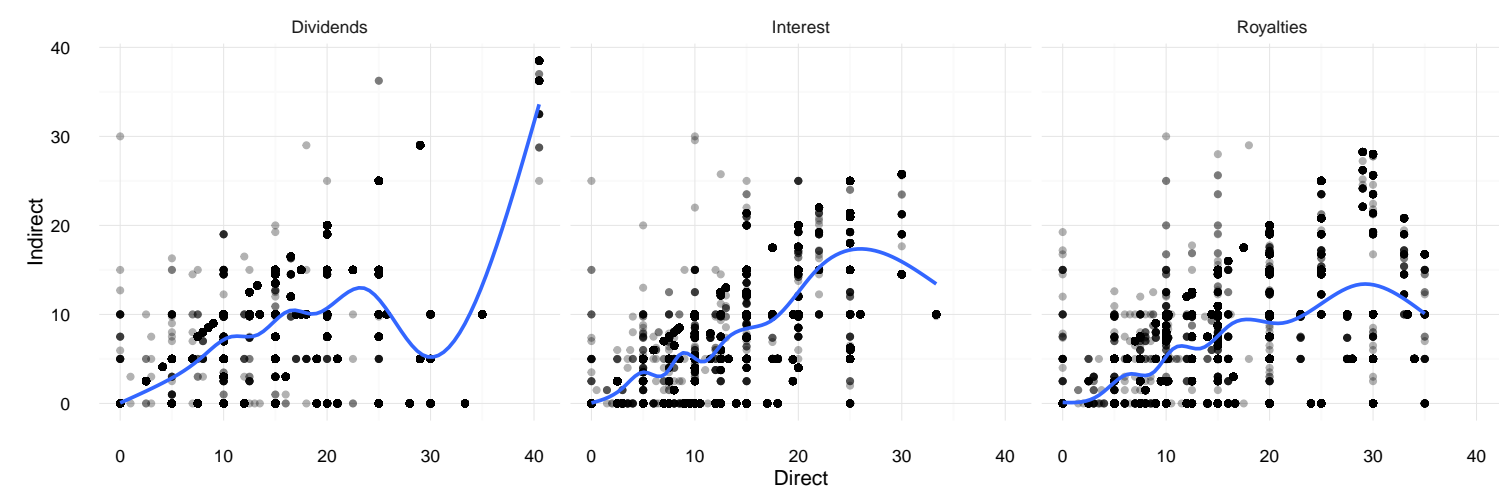

Figure 7: Direct vs. indirect withholding tax rates. 
Of course, the bivariate association shown in Figure could be driven by an omitted variable. For instance, if neighboring countries tend to sign BTTs with more favorable terms, the positive association between direct and indirect rates could be explained by geographic clustering. Similarly, a country's level of economic development may dictate both its tax policy and the thickness of the treaty network in which that country is embedded. To account for these confounding factors, I estimate linear regression models that control for inverse geographic distance 40 and GDP per capita. 11

Another threat to inference is that both direct and indirect rates could be conditioned by a country's overall stance toward international tax policy. In terms of research design, this suggests the need to control for country fixed effects (or for indirect rates country averages). However, as I pointed out earlier, one of the main consequences of treaty shopping is a drastic reduction in the within-country variance in rate. This is an important and interesting feature of the phenomenon but unfortunately, since I do not have access to panel data, and because nearly all the relevant variance is cross-sectional, it precludes the use of within/demeaned regression models. As a second-best approach, I control for host country baseline (i.e., non-treaty) withholding tax rates, and for the number of BTTs that they have concluded.

Finally, to distinguish between the tax competition and treaty-shopping dynamics (Figure ), I construct variables of the form described as "specific source contagion" by Neumayer and Plümper. ${ }^{42}$ The resulting model can be represented as:

$$
\tau_{i j}=\beta_{0}+\beta_{1} \tau_{i j}^{\prime}+\beta_{2} \sum_{k \notin\{i, j\}} \omega_{i k} \tau_{k j}+\Gamma \mathbf{X}+\epsilon_{i j}
$$

where $\tau_{i j}$ is the direct withholding tax rate on flows from $i$ and $j, \tau_{i j}^{\prime}$ is the indirect rate, $\mathbf{X}$ is a vector of control variables, $\epsilon_{i j}$ is a disturbance term, and the weight $\omega_{i k}$ is an indicator variable for whether $i$ and $k$ are geographically contiguous. 13

If treaty shopping acts as a constraint on policymaking, we should see $\beta_{1}>0$ (InDiRect RATE). If conventional tax competition drives policy, we should see $\beta_{2}>$ 0 (CONTAGION).

Estimating the model in Equation 2 by ordinary least squares yields results that are consistent with these expectations (Table 11). All three of the coefficients associated with indirect rate variables are positive and statistically distinguishable from zero. The magnitude of the relationship also seems substantively important, with a

\footnotetext{
${ }^{40}$ Mayer and Zignago 2006

${ }^{41}$ World Bank 2014

${ }^{42}$ Neumayer and Plümper 2010, Eq.6

${ }^{43}$ The block-diagonal contiguity matrix that I used for weights was row-normalized.
} 
Table 1: Relationship between direct and indirect withholding tax rates. OLS regression models with heteroskedasticity-consistent standard errors.

\begin{tabular}{lccc}
\hline & Interest & Royalties & Dividends \\
\hline Intercept & 13.868 & 20.932 & 5.724 \\
& $(0.802)$ & $(0.885)$ & $(0.676)$ \\
Indirect rate & 0.439 & 0.295 & 0.169 \\
& $(0.019)$ & $(0.019)$ & $(0.015)$ \\
Contagion & 0.141 & 0.062 & 0.166 \\
& $(0.015)$ & $(0.013)$ & $(0.015)$ \\
$\log (\mathrm{GDP} /$ cap) host & -0.175 & -0.549 & -0.141 \\
& $(0.053)$ & $(0.060)$ & $(0.056)$ \\
$\log (\mathrm{GDP} /$ cap$)$ home & -0.603 & -0.893 & 0.376 \\
& $(0.045)$ & $(0.049)$ & $(0.050)$ \\
Geographic proximity & -0.624 & -0.759 & -0.217 \\
& $(0.068)$ & $(0.067)$ & $(0.073)$ \\
Baseline rate & -0.004 & 0.036 & 0.078 \\
& $(0.012)$ & $(0.010)$ & $(0.011)$ \\
$\log (\mathrm{BTTs})$ & -0.115 & -0.226 & 0.302 \\
& $(0.126)$ & $(0.142)$ & $(0.089)$ \\
\hline $\mathrm{R}^{2}$ & 0.304 & 0.289 & 0.159 \\
Adj. $\mathrm{R}^{2}$ & 0.303 & 0.288 & 0.158 \\
Num. obs. & 3971 & 4114 & 4015 \\
RMSE & 3.971 & 4.124 & 4.497 \\
\hline
\end{tabular}

1 percentage point decrease in the indirect withholding tax associated with a cut of about 0.3 in bilateral rates.

Reassuringly, the other coefficient estimates also behave roughly as expected: GEOGRAPHIC PROXIMITY is negatively related to bilateral tax rates, and richer countries sign deeper agreements. There is also evidence of specific source contagion (i.e., tax competition), with positive and statistically significant coefficients for the Contagion variables.

\footnotetext{
${ }^{44}$ Interestingly, the coefficient estimates for the LOG(BTTs) variable do not show consistent signs across model specifications and flow types. This suggests that the governments who are most active in signing BTTs do not systematically agree to deeper cuts in withholding taxes. As a reviewer notes, however, the substantive interpretation of this coefficient is complicated by the fact that INDIRECT RATES could be understood as a post-treatment control with respect to LOG(BTTs).
} 


\section{Robustness}

I took several steps to ensure that these findings are robust: (1) The measure of INDIRECT RATES that I used in Table 1 allowed for only those corporate structures that relied on one intermediary in a single third-party country. To generalize the insight, I constructed a different variable that measures the cheapest indirect rate with an unlimited number of intermediate nodes, using a modified version of the FloydWarshall algorithm. (2) Some governments apply different withholding tax rates to different types of firms (i.e., industry-based discrimination). In Table 1, I considered the median withholding tax bracket. In alternative specifications, I use the bottom or top rates for each flow type. (3) Instead of controlling for GDP per capita, I use the GDP. I also add a measure of economic asymmetry between host and home countries (squared difference in GDP per capita). (4) Since most of the variance occurs across rather than within host countries, using dyadic data may overstate the statistical significance of my findings. I thus re-estimate the baseline models using country-wise averages of each variable. (5) I re-estimate the models in Table 1 using effective tax rates instead of treaty rates as the dependent variable. (6) Instead of using dummy variables as weights in the contiguity matrix, I re-estimate the models using a continuous, population-weighted inverse distance variable. (7) The set of competitor countries that governments look to when setting policies may depend on economic fundamentals rather than geography. I compute a new set of weights by taking the correlation between $i$ and $k$ 's respective agriculture, manufacturing, industry and services sector shares of the economy. I then use these weights instead of geographic contiguity to capture specific source contagion. (8) To guard against the possibility that outliers drive the results, I re-estimated the baseline models using a robust linear M-estimator. (9) Since withholding tax rates are bounded from below at zero, I replicated the results from Table 1 using a Tobit model. (10) I reestimate the baseline models without controlling for the number of BTTs.

Results from these robustness checks, along with replication materials, appear online in the supplementary materials. The only substantive difference between those results and the ones presented here is that the CONTAGION variable is not consistently signed across types of flows and contiguity matrix specifications.

\section{Summary of Findings}

The evidence I have presented is useful for both description and hypothesis testing. On the descriptive side, I showed that BTTs lead to deep cuts in applicable withholding tax rates, both directly through bilateral concessions and indirectly by allowing firms to make payments through conduits. In addition, treaty shopping appears to act as an equalizing force, stripping host governments of their ability to price-discriminate between home countries. 
In terms of hypothesis testing, I examined the relationship between direct and indirect withholding taxes, to determine if bilateral agreements produce negative fiscal externalities. Where the proliferation of BTTs empowers MNCs to make cheap indirect payments, I found that governments maintain lower (direct) tax rates. Put simply, states seem to be constrained by the unintended consequences of a regime that they have themselves created.

Of course, such partial correlations should not be mistaken for properly identified causal effects. Still, the fact that relevant coefficients are consistently positive, large, and statistically significant is highly suggestive. The positive association between direct and indirect tax rates subsists, even after we control for more traditional patterns of spatial dependence between jurisdictions. Treaty shopping and tax competition are theoretically and empirically distinct phenomena.

\section{DISCUSSION}

A large body of works in political science examine the causes and consequences of international governance through complex regimes. Most of that research focuses on choice of law by states. I have studied what happens when private actors can exploit regime complexity for profit. By resolving a politically charged coordination problem through bilateralism, states have empowered multinationals to shop for and mold the legal environment in which they operate. The treaty-shopping opportunities that the proliferation of BTTs creates, in turn, have come to restrict state autonomy.

These findings point to an unexplored set of constraints on public policy. They also throw into sharp relief key features of related problems in international political economy. For instance, we know that foreign investors sometimes establish subsidiaries outside their home or host to gain standing in investor-state disputesettlement proceedings governed by strong bilateral investment treaties. In the CME case, for example, an American "investor used a holding company in the Netherlands to launch parallel claims against the Czech Republic under two separate investment treaties in relation to the same dispute., 45

By raising complaints indirectly, from a third-party country, firms can exploit the network of bilateral relationships between states to reshape the environment in which they invest. As in the tax case, governments' ability to regulate the actions of multinationals depends on bilateral concessions and on spillovers from agreements with third parties.

States face similar issues when they conclude preferential trade agreements and wish to avoid trade deflection. Here again, firms can leverage regime complexity by shipping goods indirectly, first to the country with the lowest external tariff, and

\footnotetext{
${ }^{45}$ Harten and Loughlin 2006, 139
} 
then to its final destination in the free-trade area. As with international taxes, understanding trade as a purely bilateral phenomenon can be misleading. 16

Despite the similar problem structures that we find in international investment, taxation, and trade, outcomes in those three issue areas have been markedly different. Unlike governments' anti-abuse initiatives in the first two fields, rules of origin have been quite successful at preventing MNCs from exploiting the structure of the trade treaty network to jump tariffs.

One key explanation for this disparity lies in the fundamentally different ways in which treaties delineate the set of entities that can claim protection. On the one hand, tax treaty benefits and standing in investment disputes are typically conferred to firms that meet formal residence criteria such as country of incorporation or location of "mind and management"; experience shows that these eligibility conditions are relatively easy to manipulate by companies. 17 On the other hand, to qualify for reduced tariffs under a preferential trade agreement, products must generally conform to rules of origin that discriminate based on the geographic location of the transformative economic activity; this factor is arguably harder for firms to change without incurring large relocation costs.

This highlights some of the conditions under which global economic governance through complex regimes can yield undesirable outcomes. When the protection of international law is granted based on criteria that are manipulable by the regulated entities, private actors should be expected to engage in treaty shopping, and their actions may undermine public policy goals. 18 This problem is compounded when governance is conducted through decentralized networks of bilateral agreements, because the actions of individual governments can reverberate through the treaty network to produce negative externalities. Where we cannot put in place discriminatory mechanisms to hinder treaty shopping by private actors, the harmonization of policies through multilateral agreement or under the aegis of an international organization seems highly desirable.

\footnotetext{
${ }^{46}$ Ward, Ahlquist, and Rozenas 2013

${ }^{47}$ As Gray 2016 points out, a few arbitral panels have rejected claims in egregious cases of investment treaty shopping, but the practice remains widespread.

${ }^{48}$ Several observers have picked up on that distinction and pushed to strengthen the link between tax base allocation and the geographic distribution of sales and factors of production. In 2015-2016, for instance, House Republicans unveiled a tax reform blueprint based on the idea of a Destination-Based Cash Flow Tax, the European Commission made small steps toward the adoption of a Common Consolidated Corporate Tax Base, and reform-minded academics argued for the adoption of a worldwide formulary apportionment system (e.g., Dietsch, 2015).
} 


\section{SUPPLEMENTARY MATERIAL}

Supplementary material for this research note is available at http://arelbundock. com

\section{REFERENCES}

Alter, Karen J, and Sophie Meunier. 2009. The Politics of International Regime Complexity. Perspectives on politics 7 (01):13-24.

Avi-Yonah, Reuven S. 2007. International Tax as International Law: An Analysis of the International Tax Regime. Cambridge Tax Law Series. New York: Cambridge University Press.

Barthel, Fabian, Matthias Busse, and Eric Neumayer. 2009. The Impact of Double Taxation Treaties on Foreign Direct Investment: Evidence from Large Dyadic Panel Data. International Studies Quarterly 28 (3):366-77.

Barthel, Fabian, and Eric Neumayer. 2012. Competing for Scarce Foreign Capital: Spatial Dependence in the Diffusion of Double Taxation Treaties. International Studies Quarterly 56 (4):645-60.

Blonigen, Bruce A., and Ronald B. Davies. 2004. The Effects of Bilateral Tax Treaties on US FDI activity. International Tax and Public Finance 11 (5):601-22.

Busch, Marc L. 2007. Overlapping Institutions, Forum Shopping, and Dispute Settlement in International Trade. International Organization 61 (04):735-61.

Carroll, Mitchell B. 1939. Prevention of international double taxation and fiscal evasion - Two decades of progress under the League of Nations. Geneva: League of Nations.

Carroll, Mitchell Benedict. 1978. Global Perspectives of an International Tax Lawyer. Hicksville, NY: Exposition Press.

Christians, Allison, and Arthur J. Cockfield. 2014. Submission to Finance Department on Implementation of FATCA in Canada: Submission on Legislative Proposals to the Canada-United States Enhanced Tax Information Exchange Agreement. Available at SSRN: https://ssrn.com/abstract=2407264 or http://dx.doi.org/10.2139/ssrn.2407264.

Clausing, Kimberly A. 2009. Multinational firm tax avoidance and tax policy. $\mathrm{Na}$ tional Tax Journal 62 (4):703-25. 
Crandall, Frith. 1988. Termination of the United States-Netherlands Antilles Tax Treaty: What Were the Costs of Ending Treaty Shopping. Northwestern Journal of International Law \& Business 9:355-81.

Darby, J. B., and Kelsey Lemaster. 2007. Double Irish more than Doubles the Tax Savings. Practical US/International Tax Strategies 11 (9):2-16.

De, Prabir, Selim Raihan, and Syed Ejaz Ghani. 2013. What Does MFN Trade Mean for India and Pakistan? Can MFN Be a Panacea? Policy Research Working Paper 6483, The World Bank.

Dharmapala, Dhammika. 2014. What Do We Know About Base Erosion and Profit Shifting? A Review of the Empirical Literature. Fiscal Studies 35 (4):421-48.

Dietsch, Peter. 2015. Catching Capital: The Ethics of Tax Competition. New York: Oxford University Press.

Drucker, Jesse. 2010. Google 2.4\% Rate Shows How \$60 Billion Lost to Tax Loopholes. Bloomberg. https://www.bloomberg.com/news/2010-10-21/ google-2-4-rate-shows-how-60-billion-u-s-revenue-lost-to-tax-loopholes. html/.

European Commission. 2015. Commission Decides Selective Tax Advantages for Fiat in Luxembourg and Starbucks in the Netherlands are Illegal Under EU State Aid Rules. http://europa.eu/rapid/press-release_IP-15-5880_en. htm.

Findley, Michael G, Daniel L Nielson, Jason Sharman, and Jason Campbell Sharman. 2014. Global Shell Games: Experiments in Transnational Relations, Crime, and Terrorism. New York: Cambridge University Press.

Gray, Julia C. 2016. Jumping Someone Else's Treaty: Investor-State Dispute Settlement and Treaty Shopping. Working Paper.

Hale, Thomas, David Held, and Kevin Young. 2013. Gridlock: From Selfreinforcing Interdependence to Second-order Cooperation Problems. Global Policy 4 (3):223-35.

Harten, Gus Van, and Martin Loughlin. 2006. Investment Treaty Arbitration as a Species of Global Administrative Law. European Journal of International Law $17(1): 121-50$.

Haug, Simone M. 1996. The United States Policy of Stringent Anti-Treaty-Shopping Provisions: A Comparative Analysis. Vanderbilt Journal of Transnational Law 29:191-289. 
Hines, James R., Jr. 2014. How Serious Is the Problem of Base Erosion and Profit Shifting? Canadian Tax Journal 62 (2):443-453.

Internal Revenue Service. 2004. Passive Activity Loss ATG - Chapter 3, Passive Income. http://www.irs. gov/Businesses/Small-Businesses-\&-Self-Employed/ Passive-Activity-Loss-ATG-Chapter-3-Passive-Income.

-_- 2010. Foreign Recipients of US Income. Tech. rep. Table 2. Forms 1042S: Number, US Tax Withheld, and U.S.-Source Income, by Principal Type of Income, Selected Recipient Type, and Selected Country.

International Consortium of Investigative Journalists. 2014. Luxembourg Leaks: Global Companies' Secrets Exposed. http://www.icij.org/project/luxembourgleaks.

Jervis, Robert. 1998. System Effects: Complexity in Political and Social Life. Princeton, NJ: Princeton University Press.

Kandev, Michael. 2009. Treaty Shopping After Prevost Car: What Does the Future Hold. https://www.dwpv.com/ /media/Files/PDF_EN/2014-2007/ Treaty_Shopping_After_Prevost_Car_-_What_Does_The_Future_ Hold.ashx.

Kelley, Judith. 2009. The More the Merrier? The Effects of Having Multiple International Election Monitoring Organizations. Perspectives on Politics 7 (1):59-64.

Kleinbard, Edward D. 2011. Stateless Income. Florida Tax Review 11 (9):700-73.

Mayer, Thierry, and Soledad Zignago. 2006. GeoDist: the CEPII Distances and Geographical Database. http://www.cepii.fr/CEPII/en/bdd_modele/bdd. asp.

Neumayer, Eric, and Thomas Plümper. 2010. Spatial Effects in Dyadic Data. International Organization 64 (1):145-66.

OECD. 1964. Final Report on the Fiscal Incentives in Capital Exporting Countries for Private Investment in Developing Countries - FC(64)2. http://www . taxtreatieshistory.org/.

- - . 1967. Third Report on Tax Avoidance Through the Improper Use or Abuse of Tax Conventions - FC-WP21(67)1E. http://www. taxtreatieshistory . org/. 
Pekkanen, Saadia M, Mireya Solís, and Saori N Katada. 2007. Trading Gains for Control: International Trade Forums and Japanese Economic Diplomacy. International Studies Quarterly 51 (4):945-70.

Raustiala, Kal, and David G Victor. 2004. The Regime Complex for Plant Genetic Resources. International Organization 58 (2):277-309.

Rixen, Thomas. 2008. The Political Economy of International Tax Governance. Basingstoke, UK: Palgrave MacMillan.

- - 2010. Bilateralism or Multilateralism? The Political Economy of Avoiding International Double Taxation. European Journal of International Relations $16(4): 589-14$.

- - . 2011. From Double Tax Avoidance to Tax Competition: Explaining the Institutional Trajectory of International Tax Governance. Review of International Political Economy 18 (2):197-227.

Rixen, Thomas, and Peter Schwarz. 2009. Bargaining Over the Avoidance of Double Taxation: Evidence from German Tax Treaties. FinanzArchiv: Public Finance Analysis 65 (4):442-71.

Rodrik, Dani. 1997. Has Globalization Gone Too Far? Washington DC: Institute for International Economics.

Ruggie, John Gerard. 1992. Multilateralism: the Anatomy of an Institution. International Organization 46 (3):561-98.

Strange, Susan. 1996. The Retreat of the State: The Diffusion of Power in the World Economy. Cambridge UK: Cambridge University Press.

Ward, Michael D., John S. Ahlquist, and Arturas Rozenas. 2013. Gravity's Rainbow: A Dynamic Latent Space Model for the World Trade Network. Network Science $1(1): 95-118$.

Weichenrieder, Alfons J, and Jack Mintz. 2008. What Determines the Use of Holding Companies and Ownership Chains. Centre for Business Taxation Working Paper WP08/03. Oxford, UK: Oxford University. .

Weiss, Linda. 1998. The Myth of the Powerless State. Ithaca, NY: Cornell University Press.

Weyzig, Francis. 2013. Tax Treaty Shopping: Structural Determinants of Foreign Direct Investment Routed Through the Netherlands. International Tax and Public Finance 20 (6):910-37. 
World Bank. 2014. World Development Indicators. http://data . worldbank. org. 


\section{SUPPLEMENTARY MATERIAL}


Table A1: Floyd-Warshall

\begin{tabular}{lccc}
\hline & Interest & Royalties & Dividends \\
\hline Intercept & 16.297 & 23.469 & 5.952 \\
& $(0.783)$ & $(0.838)$ & $(0.679)$ \\
Indirect rate & 0.426 & 0.262 & 0.148 \\
& $(0.022)$ & $(0.024)$ & $(0.015)$ \\
Contagion & 0.132 & 0.069 & 0.158 \\
& $(0.015)$ & $(0.013)$ & $(0.015)$ \\
$\log (\mathrm{GDP} /$ cap) host & -0.297 & -0.740 & -0.147 \\
& $(0.054)$ & $(0.059)$ & $(0.056)$ \\
$\log (\mathrm{GDP} /$ cap) home & -0.659 & -0.934 & 0.370 \\
& $(0.045)$ & $(0.049)$ & $(0.050)$ \\
Geographic proximity & -0.618 & -0.788 & -0.261 \\
& $(0.069)$ & $(0.068)$ & $(0.073)$ \\
Baseline rate & 0.003 & 0.040 & 0.086 \\
& $(0.013)$ & $(0.010)$ & $(0.011)$ \\
$\log (\mathrm{BTTs})$ & -0.240 & -0.262 & 0.325 \\
& $(0.125)$ & $(0.143)$ & $(0.088)$ \\
\hline $\mathrm{R}^{2}$ & 0.278 & 0.271 & 0.151 \\
Adj. $\mathrm{R}^{2}$ & 0.277 & 0.270 & 0.150 \\
Num. obs. & 3971 & 4114 & 4015 \\
RMSE & 4.044 & 4.175 & 4.517 \\
\hline
\end{tabular}


Table A2: Minimum withholding tax bracket

\begin{tabular}{lccc}
\hline & Interest & Royalties & Dividends \\
\hline Intercept & 20.534 & 25.838 & 4.419 \\
& $(0.882)$ & $(0.936)$ & $(0.696)$ \\
Indirect rate & 0.271 & 0.214 & 0.197 \\
& $(0.029)$ & $(0.024)$ & $(0.015)$ \\
Contagion & 0.095 & 0.040 & 0.198 \\
& $(0.020)$ & $(0.015)$ & $(0.015)$ \\
$\log (\mathrm{GDP} /$ cap) host & -0.430 & -0.711 & -0.001 \\
& $(0.068)$ & $(0.068)$ & $(0.055)$ \\
$\log (\mathrm{GDP} /$ cap) home & -0.801 & -1.070 & 0.402 \\
& $(0.052)$ & $(0.050)$ & $(0.051)$ \\
Geographic proximity & -0.723 & -0.763 & -0.440 \\
& $(0.083)$ & $(0.073)$ & $(0.076)$ \\
Baseline rate & 0.049 & 0.044 & 0.039 \\
& $(0.016)$ & $(0.009)$ & $(0.010)$ \\
$\log (\mathrm{BTTs})$ & -0.626 & -0.668 & 0.378 \\
& $(0.139)$ & $(0.145)$ & $(0.091)$ \\
\hline $\mathrm{R}^{2}$ & 0.208 & 0.272 & 0.155 \\
Adj. R & 0.206 & 0.271 & 0.153 \\
Num. obs. & 3971 & 4114 & 4015 \\
RMSE & 4.754 & 4.404 & 4.686 \\
\hline
\end{tabular}


Table A3: Maximum withholding tax bracket

\begin{tabular}{lccc}
\hline & Interest & Royalties & Dividends \\
\hline Intercept & 13.164 & 18.728 & 6.605 \\
& $(0.789)$ & $(0.879)$ & $(0.692)$ \\
Indirect rate & 0.362 & 0.314 & 0.163 \\
& $(0.014)$ & $(0.017)$ & $(0.014)$ \\
Contagion & 0.088 & 0.066 & 0.125 \\
& $(0.010)$ & $(0.012)$ & $(0.013)$ \\
$\log (\mathrm{GDP} /$ cap) host & -0.231 & -0.492 & -0.150 \\
& $(0.054)$ & $(0.063)$ & $(0.056)$ \\
$\log (\mathrm{GDP} /$ cap) home & -0.529 & -0.760 & 0.357 \\
& $(0.048)$ & $(0.052)$ & $(0.050)$ \\
Geographic proximity & -0.715 & -0.859 & -0.070 \\
& $(0.070)$ & $(0.075)$ & $(0.074)$ \\
Baseline rate & 0.028 & 0.023 & 0.074 \\
& $(0.007)$ & $(0.009)$ & $(0.009)$ \\
$\log (\mathrm{BTTs})$ & 0.116 & 0.042 & 0.218 \\
& $(0.123)$ & $(0.146)$ & $(0.091)$ \\
\hline $\mathrm{R}^{2}$ & 0.288 & 0.257 & 0.140 \\
Adj. R & 0.287 & 0.256 & 0.139 \\
Num. obs. & 3971 & 4114 & 4015 \\
RMSE & 4.202 & 4.471 & 4.538 \\
\hline
\end{tabular}


Table A4: Control for GDP and asymmetry in GDP/capita.

\begin{tabular}{lccc}
\hline & Interest & Royalties & Dividends \\
\hline Intercept & 14.122 & 22.948 & -12.648 \\
& $(1.345)$ & $(1.377)$ & $(1.321)$ \\
Indirect rate & 0.454 & 0.371 & 0.165 \\
& $(0.019)$ & $(0.019)$ & $(0.014)$ \\
Contagion & 0.193 & 0.137 & 0.137 \\
& $(0.014)$ & $(0.013)$ & $(0.014)$ \\
$\log (\mathrm{GDP})$ host & -0.214 & -0.394 & 0.284 \\
& $(0.047)$ & $(0.052)$ & $(0.042)$ \\
$\log (\mathrm{GDP})$ home & -0.080 & -0.263 & 0.458 \\
& $(0.034)$ & $(0.036)$ & $(0.034)$ \\
GDP/capita asymmetry & -0.121 & -0.142 & 0.154 \\
& $(0.023)$ & $(0.025)$ & $(0.025)$ \\
Geographic proximity & -0.698 & -0.905 & 0.231 \\
& $(0.074)$ & $(0.074)$ & $(0.076)$ \\
Baseline rate & -0.000 & 0.052 & 0.054 \\
& $(0.012)$ & $(0.011)$ & $(0.010)$ \\
$\log (\mathrm{BTTs})$ & 0.419 & 0.657 & 0.040 \\
& $(0.161)$ & $(0.187)$ & $(0.094)$ \\
\hline R & 0.282 & 0.245 & 0.203 \\
Adj. R & 0.281 & 0.243 & 0.202 \\
Num. obs. & 3971 & 4114 & 4015 \\
RMSE & 4.033 & 4.251 & 4.378 \\
\hline
\end{tabular}


Table A5: Between model

\begin{tabular}{lccc}
\hline & Interest & Royalties & Dividends \\
\hline Intercept & 9.715 & 8.197 & 8.010 \\
& $(1.703)$ & $(1.935)$ & $(1.633)$ \\
Indirect rate & 0.434 & 0.405 & 0.367 \\
& $(0.068)$ & $(0.074)$ & $(0.059)$ \\
$\log (\mathrm{GDP} /$ cap) host & -0.455 & -0.473 & -0.096 \\
& $(0.168)$ & $(0.158)$ & $(0.183)$ \\
Geographic proximity & -1.000 & -1.371 & 0.765 \\
& $(0.490)$ & $(0.500)$ & $(0.553)$ \\
Baseline rate & -0.023 & -0.016 & 0.034 \\
& $(0.043)$ & $(0.034)$ & $(0.040)$ \\
$\log (\mathrm{BTTs})$ & 0.399 & 0.960 & 0.655 \\
& $(0.347)$ & $(0.332)$ & $(0.306)$ \\
\hline $\mathrm{R}^{2}$ & 0.573 & 0.485 & 0.381 \\
Adj. $\mathrm{R}^{2}$ & 0.557 & 0.467 & 0.358 \\
Num. obs. & 140 & 142 & 141 \\
RMSE & 2.491 & 2.571 & 3.164 \\
\hline
\end{tabular}


Table A6: Effective withholding tax rates

\begin{tabular}{lccc}
\hline & Interest & Royalties & Dividends \\
\hline Intercept & 5.034 & 8.380 & 6.171 \\
& $(0.175)$ & $(0.282)$ & $(0.189)$ \\
Indirect rate & 0.091 & 0.086 & 0.065 \\
& $(0.005)$ & $(0.005)$ & $(0.005)$ \\
Contagion & 0.013 & 0.012 & -0.006 \\
& $(0.003)$ & $(0.004)$ & $(0.004)$ \\
$\log (\mathrm{GDP} /$ cap) host & -0.153 & -0.264 & -0.305 \\
& $(0.013)$ & $(0.020)$ & $(0.014)$ \\
$\log (\mathrm{GDP} /$ cap) home & -0.341 & -0.504 & -0.287 \\
& $(0.012)$ & $(0.017)$ & $(0.013)$ \\
Geographic proximity & -0.473 & -0.635 & -0.519 \\
& $(0.018)$ & $(0.025)$ & $(0.023)$ \\
Baseline rate & 0.856 & 0.825 & 0.847 \\
& $(0.005)$ & $(0.006)$ & $(0.005)$ \\
$\log (\mathrm{BTTs})$ & -0.260 & -0.479 & -0.197 \\
& $(0.014)$ & $(0.018)$ & $(0.019)$ \\
\hline $\mathrm{R}^{2}$ & 0.884 & 0.830 & 0.868 \\
Adj. $\mathrm{R}^{2}$ & 0.884 & 0.830 & 0.868 \\
Num. obs. & 19460 & 19460 & 19600 \\
RMSE & 2.442 & 3.380 & 2.918 \\
\hline
\end{tabular}


Table A7: Economic competition

\begin{tabular}{lccc}
\hline & Interest & Royalties & Dividends \\
\hline Intercept & 3.712 & 6.880 & 4.497 \\
& $(1.414)$ & $(1.385)$ & $(1.637)$ \\
Indirect rate & 0.413 & 0.298 & 0.165 \\
& $(0.019)$ & $(0.019)$ & $(0.015)$ \\
Contagion & 0.759 & 0.730 & 0.174 \\
& $(0.072)$ & $(0.054)$ & $(0.117)$ \\
$\log (\mathrm{GDP} /$ cap) host & -0.066 & -0.346 & -0.139 \\
& $(0.056)$ & $(0.061)$ & $(0.057)$ \\
$\log (\mathrm{GDP} /$ cap) home & -0.323 & -0.405 & 0.357 \\
& $(0.054)$ & $(0.061)$ & $(0.057)$ \\
Geographic proximity & -0.801 & -0.803 & -0.234 \\
& $(0.064)$ & $(0.065)$ & $(0.075)$ \\
Baseline rate & 0.008 & 0.049 & 0.114 \\
& $(0.012)$ & $(0.010)$ & $(0.011)$ \\
$\log (\mathrm{BTTs})$ & 0.013 & -0.301 & 0.441 \\
& $(0.125)$ & $(0.138)$ & $(0.094)$ \\
\hline $\mathrm{R}^{2}$ & 0.307 & 0.316 & 0.125 \\
Adj. $\mathrm{R}^{2}$ & 0.305 & 0.315 & 0.123 \\
Num. obs. & 3971 & 4114 & 4015 \\
RMSE & 3.963 & 4.046 & 4.588 \\
\hline
\end{tabular}


Table A8: Population-weighted inverse distance competition

\begin{tabular}{lccc}
\hline & Interest & Royalties & Dividends \\
\hline Intercept & 2.440 & 7.865 & 8.447 \\
& $(1.360)$ & $(1.258)$ & $(1.531)$ \\
Indirect rate & 0.385 & 0.273 & 0.163 \\
& $(0.019)$ & $(0.019)$ & $(0.015)$ \\
Contagion & 1.106 & 0.929 & -0.134 \\
& $(0.091)$ & $(0.062)$ & $(0.119)$ \\
$\log (\mathrm{GDP} /$ cap) host & -0.463 & -0.831 & -0.117 \\
& $(0.051)$ & $(0.058)$ & $(0.058)$ \\
$\log (\mathrm{GDP} /$ cap) home & -0.260 & -0.375 & 0.289 \\
& $(0.055)$ & $(0.061)$ & $(0.053)$ \\
Geographic proximity & -0.591 & -0.654 & -0.237 \\
& $(0.067)$ & $(0.066)$ & $(0.076)$ \\
Baseline rate & 0.012 & 0.025 & 0.114 \\
& $(0.012)$ & $(0.010)$ & $(0.011)$ \\
$\log (\mathrm{BTTs})$ & 0.122 & -0.020 & 0.442 \\
& $(0.125)$ & $(0.133)$ & $(0.094)$ \\
\hline $\mathrm{R}^{2}$ & 0.312 & 0.323 & 0.125 \\
Adj. R & 0.311 & 0.322 & 0.123 \\
Num. obs. & 3971 & 4114 & 4015 \\
RMSE & 3.947 & 4.025 & 4.588 \\
\hline
\end{tabular}


Table A9: No BTT control

\begin{tabular}{lccc}
\hline & Interest & Royalties & Dividends \\
\hline Intercept & 2.939 & 7.788 & 10.165 \\
& $(1.245)$ & $(1.151)$ & $(1.519)$ \\
Indirect rate & 0.379 & 0.274 & 0.168 \\
& $(0.018)$ & $(0.019)$ & $(0.015)$ \\
Contagion & 1.095 & 0.930 & -0.174 \\
& $(0.091)$ & $(0.062)$ & $(0.121)$ \\
$\log (\mathrm{GDP} /$ cap) host & -0.442 & -0.835 & -0.060 \\
& $(0.050)$ & $(0.055)$ & $(0.058)$ \\
$\log (\mathrm{GDP} /$ cap) home & -0.269 & -0.374 & 0.274 \\
& $(0.055)$ & $(0.060)$ & $(0.053)$ \\
Geographic proximity & -0.598 & -0.653 & -0.240 \\
& $(0.066)$ & $(0.067)$ & $(0.076)$ \\
Baseline rate & 0.013 & 0.025 & 0.114 \\
& $(0.012)$ & $(0.010)$ & $(0.011)$ \\
\hline $\mathrm{R}^{2}$ & 0.312 & 0.323 & 0.118 \\
Adj. $\mathrm{R}^{2}$ & 0.311 & 0.322 & 0.117 \\
Num. obs. & 3971 & 4114 & 4015 \\
RMSE & 3.947 & 4.024 & 4.604 \\
\hline
\end{tabular}


Table A10: Robust M-estimator

\begin{tabular}{lccc}
\hline & Interest & Royalties & Dividends \\
\hline Intercept & 14.444 & 21.786 & 5.932 \\
& $(0.810)$ & $(0.895)$ & $(0.527)$ \\
Indirect rate & 0.437 & 0.283 & 0.110 \\
& $(0.019)$ & $(0.019)$ & $(0.011)$ \\
Contagion & 0.156 & 0.071 & 0.120 \\
& $(0.015)$ & $(0.013)$ & $(0.012)$ \\
$\log (\mathrm{GDP} /$ cap) host & -0.166 & -0.537 & -0.046 \\
& $(0.054)$ & $(0.056)$ & $(0.046)$ \\
$\log (\mathrm{GDP} /$ cap) home & -0.656 & -0.947 & 0.420 \\
& $(0.045)$ & $(0.048)$ & $(0.038)$ \\
Geographic proximity & -0.652 & -0.761 & -0.231 \\
& $(0.067)$ & $(0.064)$ & $(0.054)$ \\
Baseline rate & -0.009 & 0.037 & 0.070 \\
& $(0.013)$ & $(0.010)$ & $(0.009)$ \\
$\log (\mathrm{BTTs})$ & -0.164 & -0.352 & 0.230 \\
& $(0.125)$ & $(0.137)$ & $(0.074)$ \\
\hline Num. obs. & 3971 & 4114 & 4015 \\
\hline
\end{tabular}


Table A11: Tobit

\begin{tabular}{lccc}
\hline & Interest & Royalties & Dividends \\
\hline Intercept 1 & 14.909 & 22.030 & 5.494 \\
& $(0.924)$ & $(0.965)$ & $(0.749)$ \\
Intercept 2 & 1.520 & 1.545 & 1.565 \\
& $(0.012)$ & $(0.012)$ & $(0.011)$ \\
Indirect rate & 0.483 & 0.325 & 0.184 \\
& $(0.023)$ & $(0.022)$ & $(0.016)$ \\
Contagion & 0.165 & 0.076 & 0.184 \\
& $(0.017)$ & $(0.014)$ & $(0.014)$ \\
$\log (\mathrm{GDP} /$ cap) host & $\mathbf{- 0 . 2 3 7}$ & $-\mathbf{0 . 6 1 6}$ & $-\mathbf{0 . 1 8 1}$ \\
& $(0.065)$ & $(0.066)$ & $(0.059)$ \\
$\log (\mathrm{GDP} /$ cap) home & $\mathbf{- 0 . 7 1 7}$ & $-\mathbf{1 . 0 0 5}$ & 0.382 \\
& $(0.051)$ & $(0.052)$ & $(0.052)$ \\
Geographic proximity & $\mathbf{- 0 . 7 7 6}$ & $\mathbf{- 0 . 8 7 2}$ & $-\mathbf{0 . 2 1 6}$ \\
& $(0.084)$ & $(0.086)$ & $(0.084)$ \\
Baseline rate & $\mathbf{- 0 . 0 0 7}$ & 0.042 & 0.083 \\
& $(0.014)$ & $(0.010)$ & $(0.010)$ \\
$\log (\mathrm{BTTs})$ & $-\mathbf{0 . 1 0 7}$ & $\mathbf{- 0 . 2 2 8}$ & 0.326 \\
& $(0.137)$ & $(0.139)$ & $(0.087)$ \\
\hline
\end{tabular}

